\title{
Wall-Roughness Effects on Flow and Scouring in Curved Channels with Gravel Beds
}

\author{
Daniel S. Hersberger ${ }^{1}$; Mário J. Franca²; and Anton J. Schleiss, M.ASCE ${ }^{3}$
}

\begin{abstract}
Due to a complex three-dimensional flow pattern, the outer banks of river bends are predisposed to erosion. When endangering civil structures, preventing measures to mitigate this erosion are thus required. Vertical ribs at protection walls for scour reduction have been applied to several flood protection projects in mountain rivers; nevertheless, no systematic and intensive study has been presented so far to evaluate their effect. This paper investigates experimentally the effect of vertical ribs, placed as macroroughness elements on the outer vertical wall of a $90^{\circ}$ laboratory channel bend. Systematic tests were performed using a wide and coarse grain-size distribution. Scour formation and velocity distribution were assessed in the channel in the presence of a macrorough outer bank, materialized in the laboratory by vertical elements placed on the outer vertical wall along the channel bend. Experiments showed that the macrorough outer bank changed considerably the bed morphology under equilibrium conditions. Maximum scour depth is considerably reduced by the vertical ribs placed at an optimal spacing on the bend outer wall. A considerable grain sorting process occurs across the cross section in the bend, which influences the scour process; differences are observed between situations with and without macrorough banks. The distribution of the time-averaged velocity field across the section shows the influence of the channel rough wall. An optimal macroroughness configuration in terms of scour reduction is discussed and proposed. It was observed that when spacing between vertical ribs is too reduced, these ribs act as uniformly distributed wall roughness, contributing to the width reduction due to the occupation of the cross section and increasing consequently the flow velocity with negative effects in scour reduction. DOI: 10.1061/(ASCE)HY.1943-7900.0001039. () 2015 American Society of Civil Engineers.
\end{abstract}

Author keywords: Curved channel; Secondary flow; Scour formation; Sediment transport; Wall roughness; Gravel transporting rivers.

\section{Introduction}

The flow structure and related scouring effects in bends have been studied empirically (i.e., Blanckaert and De Vriend 2004; Blanckaert and Graf 2004; Abad and Garcia 2009; Sukhodolov 2012), numerically (i.e., van Balen et al. 2009; Zeng et al. 2008), and theoretically (i.e., Odgaard and Bergs 1988; Johannesson and Parker 1989; Blanckaert et al. 2013). Fargue (1868) was probably the first to publish a formula for scour in river bends, based on field observation. Since then, several authors developed different formulations mainly in the second half of the last century.

Most of the existing formulas were developed for sand bed rivers (or uniform grain sizes) in plains and not for gravel transporting rivers with rather steep slopes. Furthermore, only a few authors have studied the effect of the macroroughness of banks in bends, having concentrated mainly on the flow behavior, such as Atsuyuki (1992), Choi (2000), and Blanckaert et al. (2010). Some examples of research on the influence of ribs placed in straight channel walls in the flow include Gairola (1996) and Rhodes and Senior (2000).

${ }^{1}$ Civil Engineer, Dr. es. Techn., Rhone Project Service des Routes et Cours d'Eaux, Etat du Valais, CH-1951 Sion, Switzerland. E-mail: daniel.hersberger@admin.vs.ch; daniel.hersberger@a3.epfl.ch

${ }^{2}$ Research and Teaching Associate, Laboratory of Hydraulic Constructions, École Polytechnique Fédérale de Lausanne, Station 18, CH-1015 Lausanne, Switzerland (corresponding author). E-mail: mario.franca@ epfl.ch

${ }^{3}$ Professor, Director of Laboratory of Hydraulic Constructions, École Polytechnique Fédérale de Lausanne, Station 18, CH-1015 Lausanne, Switzerland. E-mail: anton.schleiss@epfl.ch

Note. This manuscript was submitted on November 15, 2013; approved on March 23, 2015; published online on June 22, 2015. Discussion period open until November 22, 2015; separate discussions must be submitted for individual papers. This paper is part of the Journal of Hydraulic Engineering, (C) ASCE, ISSN 0733-9429/04015032(11)/\$25.00.
The influence of the macroroughness on the flow structure can be deduced, at least partly, based on these studies, while keeping in mind that they were not made on a bend.

Measures to prevent or mitigate the adverse effects of bendinduced morphology in rivers, specifically outer bank erosion, have been proposed by several authors. Such measures include either changing the flow patterns directly or protecting the riverbed. Examples of erosion preventing measures are utilization of riprap (Martin-Vide et al. 2010); undulated, macrorough riprap (Chèvre and Schleiss 2005); installation of bottom vanes (Odgaard and Spoljaric 1986; Odgaard and Wang 1991; Voisin and Townsend 2002) or bank-attached vanes (Bhuiyan et al. 2010); lining of the outer bank with concrete slabs (Sloff et al. 2006; Roca et al. 2007); construction of groynes or spur dikes (Przedwojski 1995; Sukhodolov et al. 2002; Jamieson et al. 2013b, a); construction of bendway weirs (Abad et al. 2008); and construction of bandal-like structures (Teraguchi et al. 2011).

Blanckaert et al. (2010, 2012) studied the influence of roughness at the outer bank in two distinct situations in a laboratory $193^{\circ}$ channel bend (Blanckaert 2002), a rectangular channel, and a trapezoidal channel with $30^{\circ}$-inclined outer bank. For the rectangular channel, Blanckaert et al. (2010) suggest that scouring close to the wall could be reduced with increasing wall roughness, whereas for the trapezoidal channel, depth-averaged downstream velocity over the bank toe is similar for all experiments regardless of the outer-bank roughness. Recently, in the very same laboratory installation, Dugué et al. (2013) proposed a solution based on the installation of a bubble screen to reduce bend scour.

Most of the aforementioned bend scour mitigation measures, especially groynes, spur dykes, and vanes, are not feasible in high-grade mountain rivers transporting coarse sediments and large boulders during floods, which would destroy such elements. Under such conditions, the banks of mountain river-crossing urban areas 


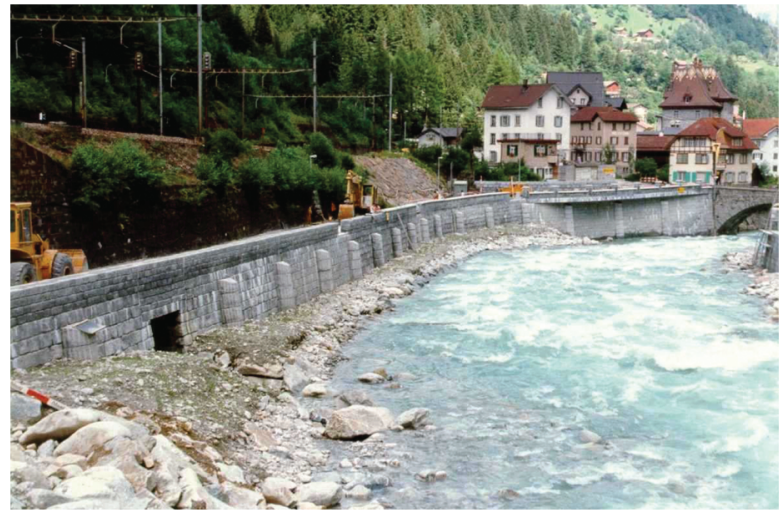

(a)

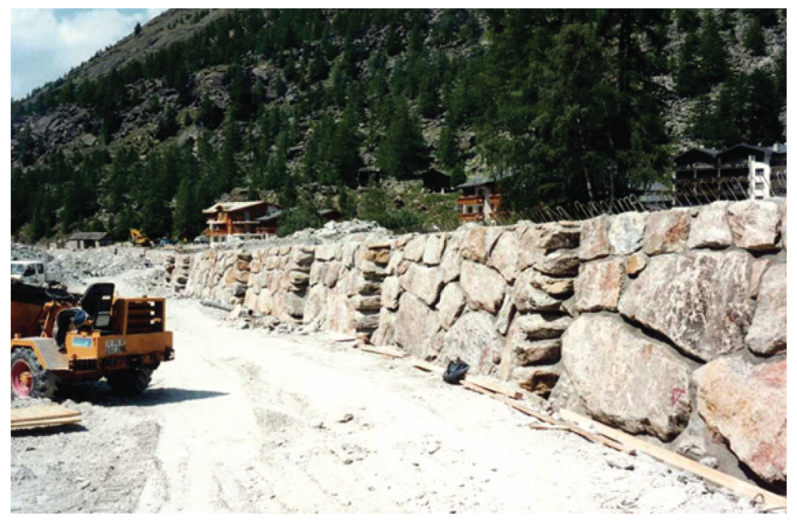

(b)

Fig. 1. (Color) Example of application of vertical ribs in outer bend banks for erosion protection (images by Anton J. Schleiss): (a) River Reuss in Gurtnellen, Switzerland; (b) under construction in River Vispa, Switzerland

have to be protected against lateral erosion by protection walls. Such walls situated in the river bend are endangered by scour if not founded deep enough. Although never systematically studied under controlled experimental conditions, practical experience of flood protections measures in high-grade mountain rivers show that vertical ribs placed in outer bank protection walls can considerably reduce scour potential and consequently reduce costs of foundation works (Schleiss 2000; examples of application are given in Fig. 1).

Atsuyuki (1992) was probably the first who studied the effect of macroroughness elements at the outer bank wall in a bend. He used small blocks placed on a grid, a so-called ladder strip and a slanting strip, which is a kind of an inclined ribbon. Atsukuyi observed that the maximum resistance to the flow is obtained when the depth of the roughness is about 10 times the spacing between the elements. Gairola (1996) studied the flow over rectangular obstructions of various aspect ratios placed on a flat bed. He observed that the separation zone behind the ribs is about 12 times the rib depth in a straight reach, which could be an indication for the optimum rib spacing.

The effect of vertical ribs, placed as macroroughness elements on the outer vertical wall of a bend, on the process of scouring has not been systematically investigated so far. Moreover, the effect of wide grain-size distribution as encountered in mountain rivers is rarely explored experimentally. To resist the impact of large boulders during floods, typically these vertical ribs have trapezoidal cross-sections, similar to the ones used in this research.

To have a better understanding of flow and scouring in curved channels with gravel beds and the effect of wall macroroughness elements, a systematic experimental investigation on a standardized $90^{\circ}$ bend was performed (Hersberger 2003) and herein reported. The tested vertical ribs correspond to a lateral protuberance of $2-4 \%$ of the river width.

After this introduction, experimental details are given. Subsequently, the results from the experimental work are presented and discussed in terms of bed morphology, water surface level, velocity distribution, optimal vertical rib positioning, and applicability. Finally, the main conclusions and recommendations are drawn.

\section{Experimental Details}

45 tests (Table 1) were performed at the Laboratory of Hydraulic Constructions $(\mathrm{LCH})$ of the École Polytechnique Fédérale de Lausanne (EPFL) on a 1.0 -m-wide laboratory flume with a $90^{\circ}$ bend
$\left(R_{c}=6.0 \mathrm{~m}\right)$ with a 7.5-m-long straight inlet reach and a 6.0-m-long straight outlet reach (Fig. 2). These tests assessed experimentally the influence of the macrorough outer walls on the flow and bed morphology, taking into account such parameters as initial longitudinal bed slope, ribs spacing, and discharge. In Table 1, experiments are codified in the form B3a, where the first capital letter (B, for example) corresponds to the initial slope and the dimension of the roughness elements, the number (3, for example) corresponds to the distance between the macroroughness elements in the channel wall, and the lower case letter (a, for example) corresponds to the discharge.

The experimental setup, shown schematically in Fig. 2, includes a sediment supplier (1, 2, and 3 in Fig. 2); an upstream water supplier system with a flow tranquilizer device (4, 5, and 6 in Fig. 2); a 7.5-m straight reach (7 in Fig. 2); a $90^{\circ}$ and $6-\mathrm{m}$-radius bend ( 8 in Fig. 2), followed by a 6.0 straight reach (9 in Fig. 2), and an outlet system that includes a tilting gate (10 in Fig. 2), a filtering basket equipped with a balance (13 in Fig. 2), and a sediment sampler (11 in Fig. 2). A measuring frame, installed on the top of the channel walls, allows the displacement of the instrumentation along the entire channel.

Tests were run with upstream sediment feeding (Fig. 2). The amount of sediments introduced at the upstream section was adjusted in order to maintain a constant bed slope and therefore equilibrium transport conditions in the channel. Before each test, an armoring layer within the curved reach was formed with a minor discharge, about $70 \mathrm{~L} / \mathrm{s}$. Then, water and sediment discharges were increased in steps until equilibrium was reached for one desired water discharge. After about $8 \mathrm{~h}$, for each discharge, the bed was stable and measurements of the water surface elevation and the bed topography were performed.

Tests were run at water discharges varying from about 120 to $210 \mathrm{~L} / \mathrm{s}$ and initial bed slopes ranging from 0.35 to $0.7 \%$, at relatively high approach Froude numbers (0.64-0.90), such as occur in mountain rivers. Configurations with and without the presence of macroroughness elements in the outer vertical walls along the bend were tested.

Grain-size distribution used in the tests, corresponding to granulometric curves of typical alpine rivers, has the following characteristics: $d_{\min }=2 \mathrm{~mm}, d_{m}=8.5 \mathrm{~mm}, \quad d_{90}=14.8 \mathrm{~mm}$, and $\sigma=\sqrt{d_{84} / d_{16}}=1.82$, where $d_{\min }$ is the minimum grain diameter, $d_{m}$ the mean diameter, $d$ the grain-size diameter corresponding to the percentage of the total amount of sediments that has smaller diameters, and $\sigma$ is a parameter characterizing the 
Table 1. Experimental Runs Parameters

\begin{tabular}{|c|c|c|c|c|c|c|c|c|c|c|}
\hline \multirow[b]{2}{*}{ Run } & \multirow[b]{2}{*}{$S_{0}(\%)$} & \multirow[b]{2}{*}{$e$ (degrees) } & \multirow[b]{2}{*}{$Q_{w}\left(\mathrm{~L} \mathrm{~s}^{-1}\right)$} & \multirow[b]{2}{*}{$Q_{s}\left(\mathrm{~kg} \min ^{-1}\right)$} & \multirow[b]{2}{*}{$h_{m}(\mathrm{~m})$} & \multirow[b]{2}{*}{ Test duration (h:min) } & \multicolumn{4}{|c|}{ Performed measurements } \\
\hline & & & & & & & $W L$ & $B T$ & $\mathrm{Vel}$ & $S S$ \\
\hline B1b & 0.5 & None & 151 & 1.579 & 0.138 & $15: 10$ & $x$ & $\times$ & $x$ & $\times$ \\
\hline B1c & & & 182 & 2.385 & 0.162 & $17: 50$ & $x$ & $\times$ & $\times$ & $\times$ \\
\hline B1d & & & 212 & 4.819 & 0.189 & $18: 55$ & $x$ & $\times$ & $x$ & $x$ \\
\hline $\mathrm{B} 2 \mathrm{~b}$ & & 4 & 151 & 0.255 & 0.156 & $17: 05$ & $x$ & $\times$ & $x$ & $\times$ \\
\hline $\mathrm{B} 2 \mathrm{c}$ & & & 183 & 0.577 & 0.181 & $16: 10$ & $x$ & $\times$ & $x$ & $\times$ \\
\hline B2d & & & 212 & 1.566 & 0.196 & $14: 20$ & $x$ & $\times$ & $x$ & $x$ \\
\hline B3b & & 2 & 151 & 0.830 & 0.145 & $14: 40$ & $x$ & $\times$ & $x$ & $\times$ \\
\hline $\mathrm{B} 3 \mathrm{c}$ & & & 183 & 0.873 & 0.178 & $16: 20$ & $x$ & $\times$ & $x$ & $x$ \\
\hline B3d & & & 213 & 1.744 & 0.195 & $17: 20$ & $x$ & $\times$ & $x$ & $x$ \\
\hline B4b & & 1 & 151 & 0.435 & 0.146 & $15: 05$ & $x$ & $\times$ & $\times$ & $\times$ \\
\hline $\mathrm{B} 4 \mathrm{c}$ & & & 182 & 0.408 & 0.171 & $15: 40$ & $x$ & $\times$ & $x$ & $\times$ \\
\hline B4d & & & 212 & 1.806 & 0.196 & $13: 00$ & $x$ & $\times$ & $x$ & $\times$ \\
\hline $\mathrm{C} 1 \mathrm{~b}$ & 0.7 & None & 151 & 3.831 & 0.134 & $12: 50$ & $x$ & $\times$ & $x$ & $\times$ \\
\hline $\mathrm{C} 1 \mathrm{c}$ & & & 182 & 6.077 & 0.151 & $12: 00$ & $x$ & $\times$ & $x$ & $\times$ \\
\hline C1d & & & 211 & 7.975 & 0.182 & $16: 15$ & $x$ & $\times$ & $\times$ & $\times$ \\
\hline $\mathrm{C} 2 \mathrm{~b}$ & & 4 & 154 & 2.336 & 0.141 & $13: 10$ & $x$ & $\times$ & $x$ & $\times$ \\
\hline $\mathrm{C} 2 \mathrm{c}$ & & & 182 & 2.355 & 0.164 & $14: 00$ & $x$ & $\times$ & $x$ & $\times$ \\
\hline $\mathrm{C} 2 \mathrm{~d}$ & & & 212 & 4.388 & 0.190 & $15: 40$ & $x$ & $\times$ & $\times$ & $\times$ \\
\hline $\mathrm{C} 3 \mathrm{~b}$ & & 2 & 151 & 1.719 & 0.150 & $15: 25$ & $x$ & $\times$ & $\times$ & $\times$ \\
\hline $\mathrm{C} 3 \mathrm{c}$ & & & 182 & 2.500 & 0.160 & $14: 55$ & $x$ & $\times$ & $x$ & $\times$ \\
\hline $\mathrm{C} 3 \mathrm{~d}$ & & & 212 & 3.464 & 0.169 & $14: 10$ & $x$ & $\times$ & $x$ & $\times$ \\
\hline $\mathrm{C} 4 \mathrm{~b}$ & & 1 & 151 & 2.244 & 0.146 & $11: 50$ & $x$ & $\times$ & $x$ & $\times$ \\
\hline $\mathrm{C} 4 \mathrm{c}$ & & & 182 & 2.321 & 0.171 & $12: 50$ & $x$ & $\times$ & $x$ & $\times$ \\
\hline $\mathrm{C} 4 \mathrm{~d}$ & & & 212 & 3.865 & 0.189 & $18: 50$ & $x$ & $\times$ & $x$ & $\times$ \\
\hline D1b & 0.35 & None & 151 & 0.693 & 0.161 & $16: 10$ & $x$ & $\times$ & $x$ & $\times$ \\
\hline D1c & & & 183 & 0.875 & 0.180 & $24: 15$ & $x$ & $\times$ & $x$ & $\times$ \\
\hline D1d & & & 211 & 1.309 & 0.189 & $18: 30$ & $\times$ & $\times$ & $x$ & $\times$ \\
\hline $\mathrm{D} 2 \mathrm{~b}$ & & 4 & 150 & 0.303 & 0.151 & $14: 20$ & $x$ & $\times$ & $\times$ & $\times$ \\
\hline $\mathrm{D} 2 \mathrm{c}$ & & & 181 & 0.767 & 0.188 & $17: 15$ & $\times$ & $\times$ & $x$ & $\times$ \\
\hline $\mathrm{D} 2 \mathrm{~d}$ & & & 211 & 1.236 & 0.207 & $17: 55$ & $x$ & $\times$ & $x$ & $\times$ \\
\hline $\mathrm{D} 3 \mathrm{~b}$ & & 2 & 150 & 0.298 & 0.158 & $14: 45$ & $x$ & $\times$ & $x$ & $\times$ \\
\hline D3c & & & 180 & 0.184 & 0.183 & $17: 25$ & $x$ & $\times$ & $\times$ & $\times$ \\
\hline D3d & & & 211 & 0.647 & 0.213 & $17: 50$ & $x$ & $\times$ & $x$ & $\times$ \\
\hline $\mathrm{D} 4 \mathrm{~b}$ & & 1 & 150 & 0.385 & 0.165 & $15: 20$ & $x$ & $\times$ & $\times$ & $\times$ \\
\hline $\mathrm{D} 4 \mathrm{c}$ & & & 181 & 0.159 & 0.187 & $18: 25$ & $x$ & $\times$ & $x$ & $\times$ \\
\hline $\mathrm{D} 4 \mathrm{~d}$ & & & 211 & $1.295^{\mathrm{a}}$ & 0.203 & $17: 40$ & $x$ & $\times$ & $x$ & - \\
\hline E2b & 0.5 & 4 & 151 & 1.174 & 0.139 & $12: 15$ & $x$ & $\times$ & - & - \\
\hline $\mathrm{E} 2 \mathrm{c}$ & & & 182 & 0.655 & 0.168 & $11: 55$ & $\times$ & $\times$ & - & - \\
\hline E2d & & & 213 & 1.040 & 0.197 & $12: 25$ & $\times$ & $\times$ & - & - \\
\hline E3b & & 2 & 151 & 0.611 & 0.157 & $12: 10$ & $x$ & $\times$ & - & - \\
\hline $\mathrm{E} 3 \mathrm{c}$ & & & 182 & 0.973 & 0.180 & $11: 35$ & $x$ & $\times$ & - & - \\
\hline E3d & & & 212 & 1.368 & 0.187 & $12: 00$ & $\times$ & $\times$ & - & - \\
\hline $\mathrm{E} 5 \mathrm{~b}$ & & 8 & 151 & 0.630 & 0.161 & $12: 10$ & $x$ & $\times$ & - & - \\
\hline $\mathrm{E} 5 \mathrm{c}$ & & & 182 & 0.731 & 0.177 & $11: 55$ & $x$ & $\times$ & - & - \\
\hline E5d & & & 213 & 1.873 & 0.191 & $26: 05$ & $x$ & $\times$ & - & - \\
\hline
\end{tabular}

Note: $B T=$ bed topography; $e=$ spacing between vertical ribs; $h_{m}=$ mean water depth upstream the bend; $Q_{s}=$ sediment discharge; $Q_{w}=$ water discharge; $S_{0}=$ initial bed slope; $S S=$ sediment sample; $\mathrm{Vel}=$ velocity; $W L=$ water level.

${ }^{\mathrm{a}}$ Computed with added sediments (at the inlet) since the outlet volume was not measured here.

scatter of the granulometric curve. Density of the sediments was $2,635 \mathrm{~kg} / \mathrm{m}^{3}$.

The wall roughness was created by positioning vertical trapezoidal ribs of two different thicknesses $\left(e_{d}\right)$, with regular spacing $(e)$ along the outer side wall (Fig. 3): at every $1^{\circ}, 2^{\circ}$, and $4^{\circ}$ for the $e_{d}=$ 20-mm-thick ribs (tests A, B, C, and D in Table 1) and at $2^{\circ}, 4^{\circ}$, and $8^{\circ}$ for the $e_{d}=40-\mathrm{mm}$-thick rib (test $\mathrm{E}$ in Table 1). Corresponding linear distances along the curved outer bank are 114, 227, 454, and $908 \mathrm{~mm}$, respectively, for $1^{\circ}, 2^{\circ}, 4^{\circ}$, and $8^{\circ}$. The ribs extended all to the bottom of the flume, which was never reached by the scour during the experiments.

During the tests, water level and bed topography were recorded with ultrasonic gauges mounted on the top of the channel on the aforementioned measuring frame (Fig. 2). In total, 32 level measurements were taken and averaged at every gauging point, giving an error on the level determination of $\pm 0.5 \mathrm{~mm}$. The water discharge was measured with an electromagnetic flow meter, which is part of the recirculating laboratory pumping circuit. Bed load was measured at the inlet (the volume of sediments introduced is controlled by the sediment supplier) and at the outlet by weighting a filtering basket installed downstream the channel (Fig. 2). For most tests, sediment samples were taken and weighted at a regular interval of $30 \mathrm{~min}$, which allowed the analysis of the time evolution of the bed load during the tests. Flow velocities were measured with an ultrasonic velocity profiler (UVP) based on Doppler effect (Hersberger 2002; Metflow 2000). Velocity profiles were acquired with a distance between sampling positions of roughly $0.011 \mathrm{~m}$, for an acquisition frequency of $77 \mathrm{~Hz}$. Three 1D probes were used 


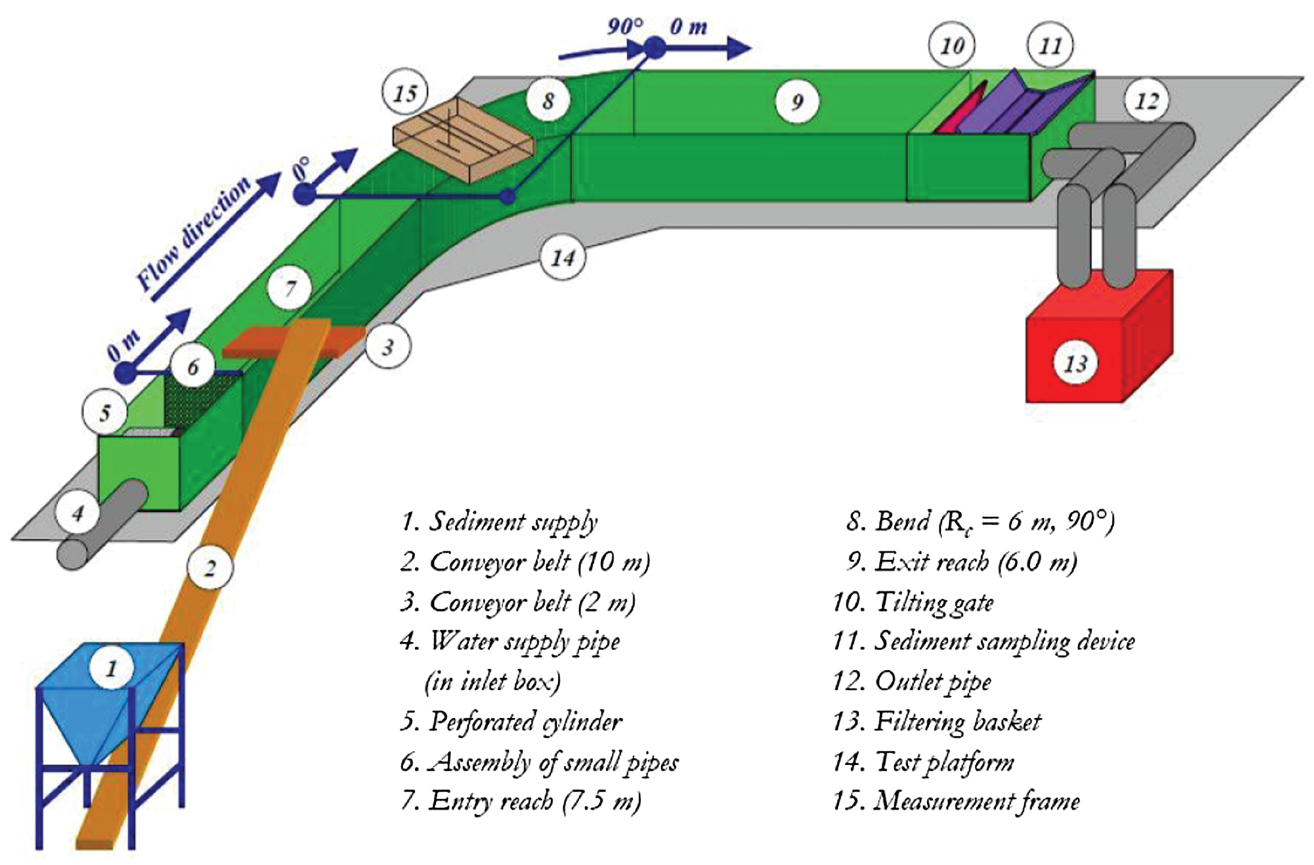

Fig. 2. (Color) Schematic view of the testing facility

attached by a device that allowed profiling in three different directions and reconstructing streamwise, spanwise, and vertical velocities. Each measurement has a different time of acquisition; the convergence of mean values for the specific acquisition times was confirmed by data analysis (see Hersberger 2003 for further details on the measurements).

\section{Results}

\section{Bed Morphology}

In all tested cases (Table 1), bed morphology acquired the typical bar-pool configuration (Odgaard 1981), characterized by a spanwise bed-slope where scouring is observed towards the outer channel bank (pool region) and deposition is observed near the inner

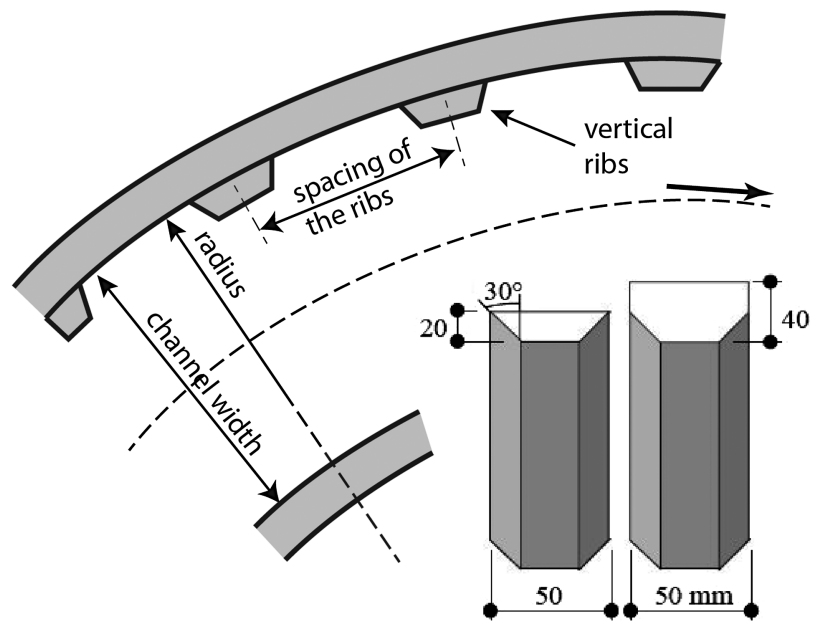

Fig. 3. Disposition and geometry of vertical ribs creating the macroroughness on the outer wall bank (bar). Moreover, generally scour near the outer wall increased with discharge, although, with this, a decrease in the relative scour is observed. The latter is characterized by the ratio $h_{s} / h_{m}$, where $h_{s}$ is the maximum scour depth and $h_{m}$ is the approach mean water depth.

Fig. 4 shows the channel bed morphology at the end of tests B1d, B2d, B3d, and B4d (Table 1) with an initial slope of $S_{0}=$ $0.5 \%$ and similar water discharges, $Q_{w} \approx 210 \mathrm{~L} / \mathrm{s}$, for the situations without ribs and with vertical ribs positioned at the outer bank at $4^{\circ}, 2^{\circ}$, and $1^{\circ}\left(e_{d}=20\right.$-mm-thick ribs $)$. Morphology is represented by bed level differences referred to an initial horizontal bed reference state.

For a smooth outer wall (B1d), two prominent scour holes were located respectively between about $30^{\circ}$ and $40^{\circ}$ (opening angle of the bend) and immediately downstream the end of the bend, extending roughly about $1 \mathrm{~m}$ (about the channel width). A first bar, located near the inner bank (local maximum in the bed topography), is roughly adjacent to the first scour hole, whereas a second bar exists ending before the second scour hole, still inside the bend.

In the presence of macroroughness elements in the outer bank (B2d, B3d, and B4d), bed morphology considerably changed. For all rib spacings, bed configuration no longer presents the two welldefined scour holes identified for the smooth bank case. Instead, the first scour hole shifts in the downstream direction and general erosion is observed along the outer side of the bend. Vertical ribs on the outer bank may reduce maximum scour depth up to $40 \%$ (discussed later). The two bars on the inner bank also disappear and a continuous elevation of the channel bed is observed in its place, contiguous to the single long erosion pit. With the reduction of the spacing of the ribs, the location of the maximum scour shifts further in the downstream direction. However, for the least-spaced ribs (B4d), topography seems again getting closer to the original situation, without macrorough outer walls. In fact, the separation between ribs is less than their respective flow separation length; thus, a wake-interference flow similar to the one described by Morris (1959) is formed, inducing instead a reduction in the usable channel width (see discussion on optimal rib positioning). Spacing 


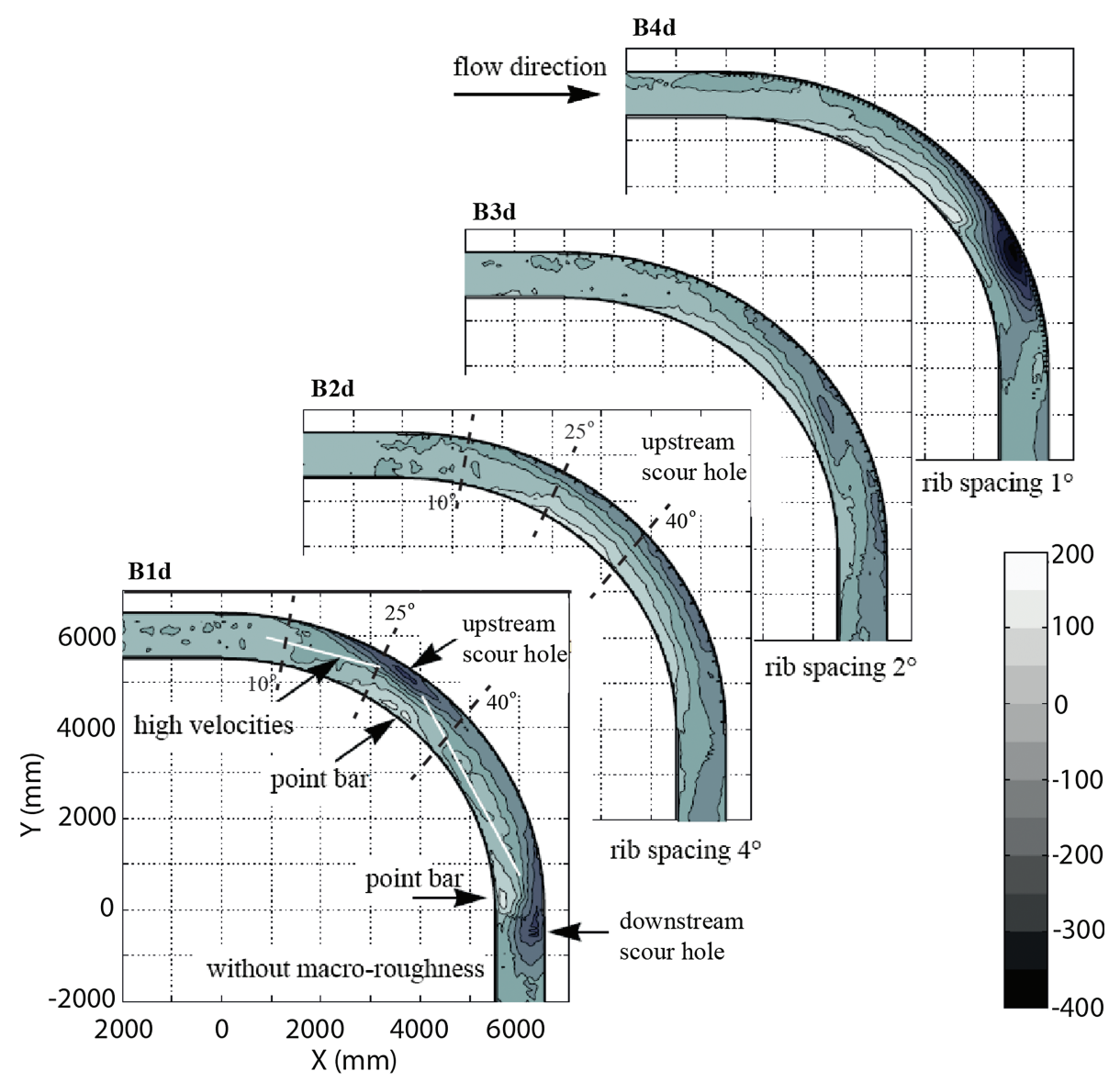

Fig. 4. (Color) Bed morphology at the end of tests B1d, B2d, B3d, and B4d (Table 1) with an initial slope of $S_{0}=0.5 \%$ and similar water discharges, $Q_{w} \approx 210 \mathrm{~L} / \mathrm{s}$, for the situations without ribs and with vertical ribs positioned at the outer bank at $4^{\circ}, 2^{\circ}$, and $1^{\circ}\left(e_{d}=20-\mathrm{mm}\right.$-thick ribs); morphology is represented by bed level differences (in $\mathrm{mm}$ ) referred to an initial horizontal bed reference state; the transects positions corresponding to $10^{\circ}, 25^{\circ}$, and $40^{\circ}$, and used in Fig. 5, are indicated in dashed lines

between ribs thus plays a role on the morphology of the channel bend and, in terms of maximum erosion depth, it may eventually represent an increase of the scouring (cf. B4d in Fig. 4).

Fig. 5 shows three transects across the channel. These represent measured water and bed levels, as well as mean water and bed levels across the section and initial bed level, taken at equilibrium situations for tests with the same initial slope of $S_{0}=0.5 \%$ and water discharge of $Q_{w} \approx 210 \mathrm{~L} / \mathrm{s}$, for the situations without ribs (run B1d) and with vertical ribs positioned at the outer bank spaced by $4^{\circ}$ (20-mm-thick ribs, run B2d). Transects correspond to two positions upstream $\left(10^{\circ}\right.$ and $\left.25^{\circ}\right)$ and one position in the downstream section of the first scour hole $\left(40^{\circ}\right)$, identified in Fig. 4 for the run without macroroughness elements (B1d).

Space evolution of the bar-pool configuration is visible from position $10^{\circ}$ to position $40^{\circ}$. For the situation with a smooth outer bank (B1d), the bed level tilts as a result of the erosion provoked by secondary cells present in the flow, forming a dune-like structure in the inner bank and a clearly visible depression in the outer bank region. Slope towards the inner bank is rather flat in the beginning, whereas towards the outer bank it is steeper. After position $10^{\circ}$, the secondary current grows and leads progressively to a more pronounced scour hole, ending in a s-shaped topography inside the scour hole. Scour holes present a point where the lateral slope changes abruptly, as observed earlier in the sinuous channel used by Reindl (1994). Overall, the scour hole moves towards the inner bank with the longitudinal development of the scour hole and the lowest point of the bed is no longer located near the outer bank. The dune-like structure also moves with the longitudinal development of the channel, this time towards the outer bank. For the downstream position at $40^{\circ}$, the highest point in the section is no longer at the inner bank but slightly distant from this.

The same general behavior can be observed in the presence of macroroughness spaced by $4^{\circ}$ (B2d), although morphological changes are dampened. In addition to the clearly observed reduction of scour deepness, lateral bed slopes are smoothened. Overall, for the case with vertical ribs shown in Fig. 5 (B2d), the amount of sediments exchanged laterally is considerably less, when compared to the situation with no macroroughness elements. The dimension of the scour hole and adjacent bank are considerably reduced as well.

Visual observations on the temporal evolution of the scour with an outer wall without ribs revealed that the first scour hole armors with coarse grains and stabilizes quickly. The second hole (Fig. 4) needs more time to stabilize. The second hole first deepens, being eventually filled again with fine sediments eroded upstream, until it finally stabilizes when an armoring layer is formed. In the case with macroroughness, the scour observed takes more time to be formed but develops continuously without oscillations. Thus, in general, the macroroughness at the outer wall contributes to a slower but smoother development of scouring in river bends.

Due to the relatively wide grain-size distribution used in the tests, as observed in mountain rivers with gravel beds, a significant grain sorting process is observed across the section. For all test areas, samples located at the deepest point of the upstream and 

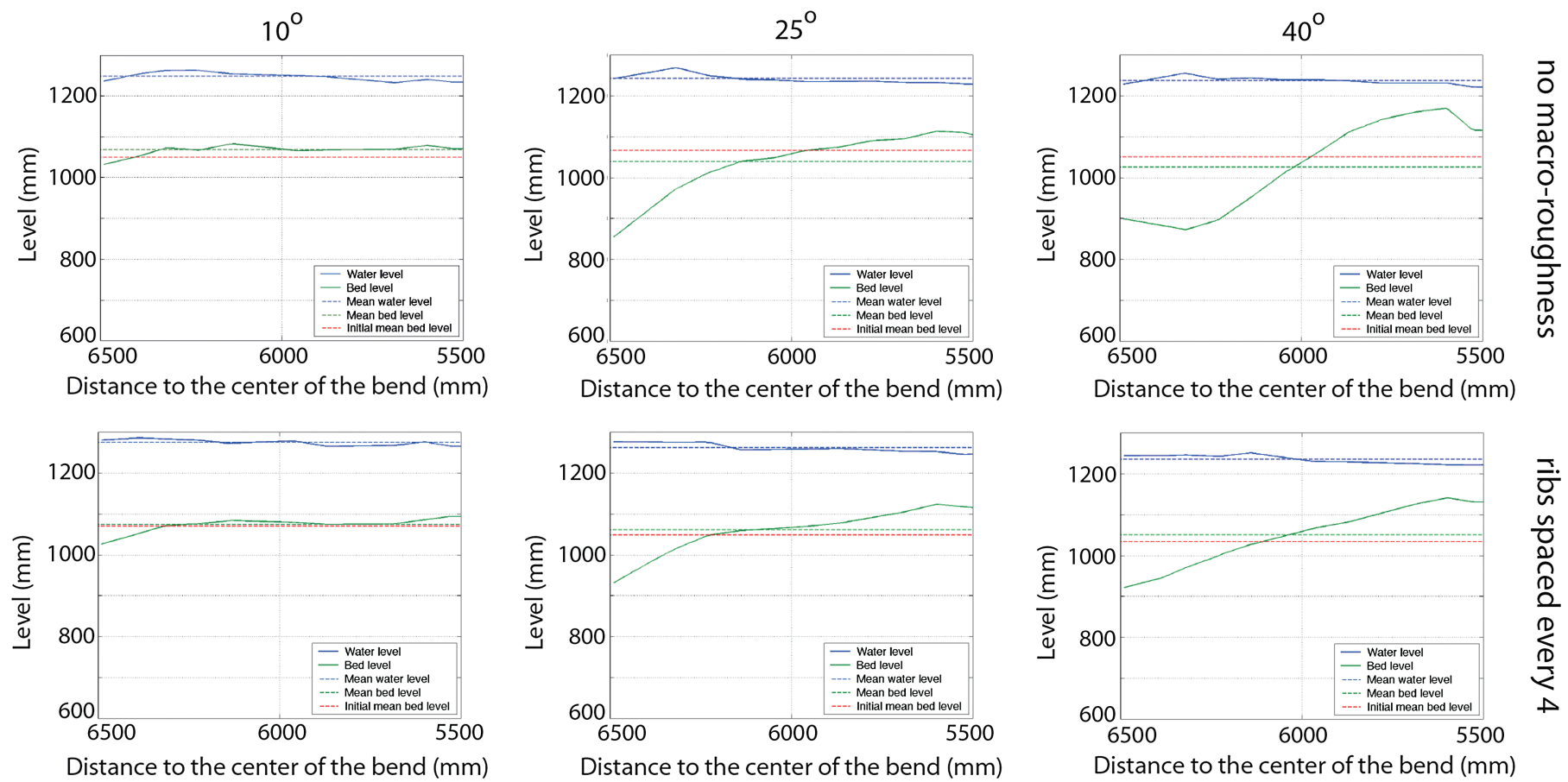

Fig. 5. (Color) Transects across the channel representing measured water and bed levels, mean water and bed levels across the section and initial bed level for tests with initial slope of $S_{0}=0.5 \%$ and water discharge of $Q_{w} \approx 210 \mathrm{~L} / \mathrm{s}$, for the situations without ribs (run B1d) and with vertical ribs positioned at the outer bank spaced by $4^{\circ}$ (20-mm-thick ribs, run B2d); transect positions correspond to $10^{\circ}, 25^{\circ}$, and $40^{\circ}$ (cf. Fig. 4 for positioning of the transects)

the downstream scour were taken at the inner and outer side. All grains located at the surface in the area of $15 \mathrm{~cm}$ width and $60 \mathrm{~cm}$ length along the flume were marked with color spray, then picked up and sampled by standard sieve analysis (Schleiss and Hersberger 2001). At the outer bank, coarse sediments form an armoring layer, whereas at the inner bank, the fine sediments are deposited. The mean grain-size diameter over the armoring layer along the outer bank is about twice as large as the mean size of the initial mixture (Schleiss and Hersberger 2001). At the inner bank, the mean size diameter of the point bar is $2 / 3$ to $3 / 4$ of the mean diameter of the initial grain mixture. This grain sorting process is similar in the presence of macrorough outer walls. Nevertheless, the zone in the scour hole, covered by a coarse armoring layer, extends to about $50 \%$ of the channel width for the case with ribs instead of $25 \%$ for the outer wall without ribs (Fig. 6). In Hersberger (2003), detailed data of the process of grain sorting in the channel are given, including grain-size distribution along the channel main features with pictures of the channel bed extensively taken.

The volumes of the scour and the point bars were measured below and above, respectively, a reference plane with a constant slope over the whole channel, fitting the flat bed surface at the inlet and at the outlet of the straight part of the channel. With and without ribs, as expected, the eroded volume at the scour holes has a tendency to increase with higher discharges. On the other hand, the slope of the channel had almost no influence on the scour volume in the range of the tested slopes $(0.35-0.70 \%)$. It could be observed that the scour volume is significantly reduced by the ribs at the channel outer bank (Hersberger 2003, p. 122). On the other hand, the volume of deposition at the point bars downstream of the scour holes is less influenced by the ribs. For the second point bar, the deposited volume remained almost constant when using the ribs. The first point bar showed a slight increase of deposited volumes for higher discharges.

\section{Water Surface}

Fig. 7 shows images from the water surface for experiments with longitudinal slope of $0.70 \%$ and discharge of about $210 \mathrm{~L} / \mathrm{s}$, for situations without ribs $(\mathrm{C} 1 \mathrm{~d})$ and with vertical ribs $(\mathrm{C} 2 \mathrm{~d}, \mathrm{C} 3 \mathrm{~d}$, and $\mathrm{C} 4 \mathrm{~d}$ ) positioned at the outer bank at $4^{\circ}, 2^{\circ}$, and $1^{\circ}$, respectively

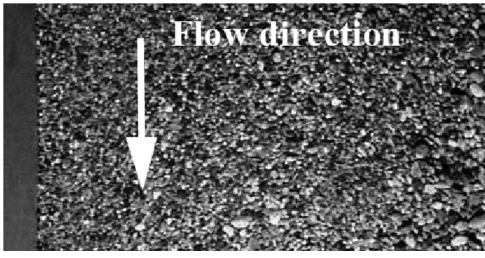

(a)
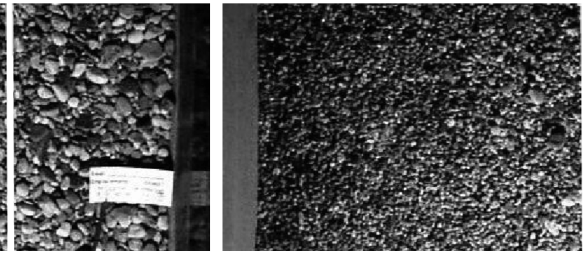

(b)

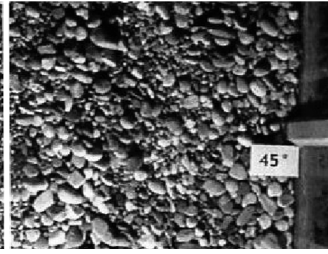

Fig. 6. Grain sorting across the channel at the scour hole (a) without ribs (b) and with vertical ribs positioned at the outer bank; the inner bank is always on the left-hand side of the image 


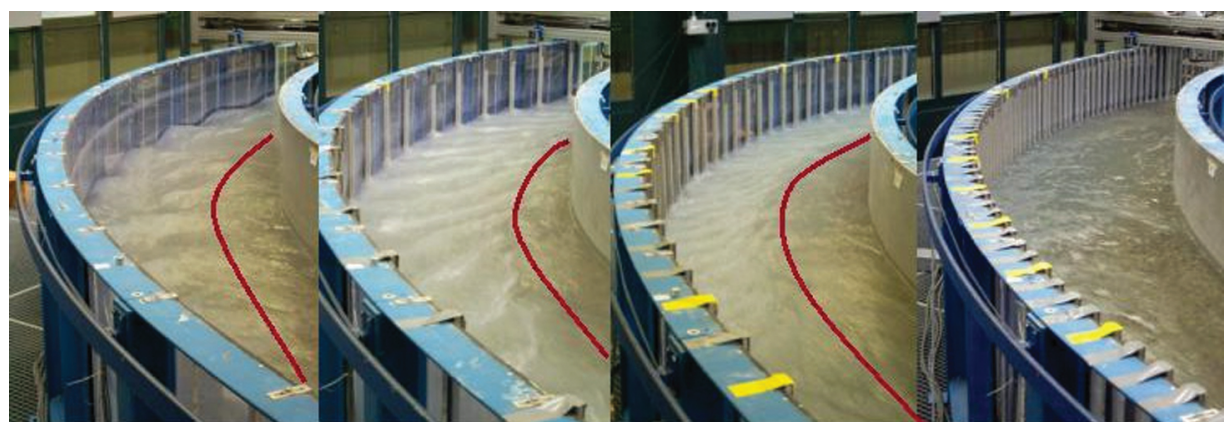

Fig. 7. (Color) Water surface for experiments with longitudinal slope of $0.70 \%$ and discharge of about $210 \mathrm{~L} / \mathrm{s}$, for situations without ribs (C1d) and with vertical ribs $(\mathrm{C} 2 \mathrm{~d}, \mathrm{C} 3 \mathrm{~d}$, and $\mathrm{C} 4 \mathrm{~d})$, positioned at the outer bank at $4^{\circ}, 2^{\circ}$, and $1^{\circ}$, respectively, from left to right in image $\left(e_{d}=20\right.$-mm-thick ribs)

( $e_{d}=20$-mm-thick ribs). Without macroroughness, stationary waves generated at the outer side wall can be observed (Fig. 7), which can reach $50 \%$ of the mean water depth, due to high local Froude numbers along the outer side of the wall. The wave length is between 3 to 5 times the mean water depth. With vertical ribs, these stationary waves are reduced to about $25 \%$ of the mean water depth and replaced by smaller shock waves, resulting from the individual separation of the flow on the macroroughness elements. The shockwaves are the result of local flow conditions near the outer bank, which are close to critical conditions or even slightly above. They emerge about $0.5^{\circ}$ upstream of the ribs and redirect the flow towards the center. Depending on the local Froude number, a deviation angle of about $50-55^{\circ}$ is observed. The waves can be observed over the outer $70 \%$ of the channel for a rib spacing of $4^{\circ}$ and over the outer $50 \%$ of the channel for a rib spacing of $2^{\circ}$ (Fig. 7 ). If the rib spacing is further reduced (rib spacing of $1^{\circ}$ ), these shockwaves disappear. The ribs no longer act as individual macroroughness elements, corresponding rather to a uniformly distributed wall roughness, which suppresses the stationary waves.

The inclination of the water surface depending on the centrifugal momentum of the flow shows no significant modification due to the presence of macroroughness. Since the ribs introduce an additional head loss in the bend, the water depth upstream the bend increases. For the tests performed, the water depth increased by 10-20\% depending on the discharge and the rib spacing. Nevertheless, the combination of the three effects-reduction of the stationary waves, increase of mean water level, and super-elevation due to the curve-did not change the highest water levels in the bend for the tested rib configurations. Thus, for practical applications, with much more wider channels compared to the rib thickness as investigated in the experiments, the backwater effect is not really an issue and normally covered by the freeboard required due to the wavy surface (Schleiss 2000).

As discussed earlier, for the smallest spacing of the ribs at every $1^{\circ}$ (Fig. 4), the scour depth can be even deeper than in the case without ribs. Only in two situations did this not happen (Table 2), and the minimum average scour reduction, calculated within the same slope, is always smaller for the spacing of the ribs at every $1^{\circ}$. If the ribs are too densely placed, they behave like a uniformly distributed wall roughness. Thus, ribs will contribute to the width reduction due to the occupation of the cross-section, increasing consequently the mean flow velocity with negative effects in scour protection measures.

\section{Mean Velocity Field}

Fig. 8 presents the cross-section distribution of the tangential (or longitudinal component) and transverse (radial and vertical components) time-averaged velocity fields for experiments with a longitudinal slope of $0.50 \%$ and discharge of about $210 \mathrm{~L} / \mathrm{s}$, for situations without ribs (B1d), and with vertical ribs positioned at the outer bank at $4^{\circ}\left(e_{d}=20\right.$-mm-thick ribs, B2d $)$. The figure presents the velocity field for the $40^{\circ}$ position, inside the scour hole formed for experiment without macrorough walls, B1d (Fig. 4).

The velocity distribution is clearly driven by topography. In the case without macroroughness, a maximum velocity cell (about 1.3 higher than the mean flow velocity) is observed near the outer bank, where the flow is channelized through the scour pit. Macroroughness in the outer bank makes this cell move towards the center of the channel.

The systematic velocity profile measurements showed that a maximum value below the free surface is observed. Ribs on the outer wall influence the tangential velocity distribution considerably. For ribs at every $4^{\circ}$, the maximum velocities are located close to the free water surface all over the bend and accounts for about 1.2 times the mean flow velocity. Furthermore, it was observed (but not shown here) that by reducing rib spacing to $2^{\circ}$, the maximum tangential velocity shifts towards the bottom but remains at a distance close to the average flow depth from the outer wall.

At the beginning of the curve, a secondary cell develops, growing up to the first scour (e.g., Bathurst et al. 1977). Another secondary but smaller cell also forms at the inner bank (Fig. 8). With ribs at every $4^{\circ}$, the main secondary current of almost constant intensity is well developed over the whole bend (Fig. 8). At the outer bank near the free water surface, a small secondary cell appears. For the performed tests, it had an almost constant intensity over the whole bend. For ribs at every $2^{\circ}$, this outer bank cell increases further. If the ribs are very dense, the outer bank cell diminishes again but is still present. It may be concluded that an eventual optimum spacing of the ribs favors the formation of a strong outer bank cell. This cell protects the bank against erosion by moving the main secondary cell towards the inner side of the bend.

\section{Considerations on Optimal Rib Positioning}

Fig. 9 shows, for all tests in Table 1, the scour reduction as a function of the ratio $e / e_{d}$ (see results from Table 2). Scour reduction is defined, within the same group of tests (same slope and same discharge, cf. Table 1), as the difference between the maximum scour depth when ribs are installed in the channel and the maximum scour depth for the situation without ribs; scour reduction is normalized by the maximum scour depth for the situation without ribs. The ratio $e / e_{d}$ represents a measure of the roughness induced by the vertical ribs, i.e., the protuberance of the ribs into the flow (represented by thickness $e_{d}$ ) relative to their density (represented by 
Table 2. Experimental Results: Scour Reduction Is Defined within the Same Group of Tests As the Difference between the Maximum Scour Depth When Ribs Are Installed in the Channel and the Maximum Scour Depth for the Situation without Ribs, Then It Is Normalized by the Maximum Scour Depth for the Situation without Ribs

\begin{tabular}{|c|c|c|c|c|c|c|c|c|c|c|}
\hline Run & $S_{0}(\%)$ & $e$ (degrees) & $Q_{w}\left(\mathrm{~L} \mathrm{~s}^{-1}\right)$ & $h_{1}(\mathrm{~m})$ & $h_{2}(\mathrm{~m})$ & $\tan \beta_{1}(-)$ & $\tan \beta_{2}(-)$ & ScLoc $_{1}$ (degrees) & $\mathrm{ScLoc}_{2}$ (degrees) & Scour reduction $(\%)$ \\
\hline B1b & 0.5 & None & 151 & 0.302 & 0.315 & 0.592 & 0.573 & 29 & 81 & 0.0 \\
\hline $\mathrm{B} 1 \mathrm{c}$ & & & 182 & 0.339 & 0.467 & 0.654 & 1.100 & 31 & 92 & 0.0 \\
\hline B1d & & & 212 & 0.392 & 0.371 & 0.644 & 0.536 & 29 & 83 & 0.0 \\
\hline $\mathrm{B} 2 \mathrm{~b}$ & & 4 & 151 & 0.258 & 0.251 & 0.401 & 0.292 & 44 & 90 & -18.1 \\
\hline $\mathrm{B} 2 \mathrm{c}$ & & & 183 & 0.295 & 0.229 & 0.329 & 0.255 & 49 & 90 & -36.8 \\
\hline B2d & & & 212 & 0.319 & 0.316 & 0.594 & 0.378 & 30 & 71 & -18.6 \\
\hline B3b & & 2 & 151 & 0.251 & 0.252 & 0.399 & 0.381 & 7 & 71 & -20.0 \\
\hline B3c & & & 183 & 0.303 & 0.281 & 0.456 & 0.466 & 60 & 89 & -35.1 \\
\hline B3d & & & 213 & 0.324 & 0.315 & 0.451 & 0.538 & 55 & 80 & -17.3 \\
\hline $\mathrm{B} 4 \mathrm{~b}$ & & 1 & 151 & 0.240 & 0.217 & 0.249 & 0.238 & 64 & 87 & -23.8 \\
\hline B 4c & & & 182 & 0.329 & 0.268 & 0.656 & 0.469 & 54 & 83 & -29.6 \\
\hline B4d & & & 212 & 0.425 & 0.494 & 0.631 & 0.655 & 55 & 71 & 26.0 \\
\hline $\mathrm{C} 1 \mathrm{~b}$ & 0.7 & None & 151 & 0.287 & 0.336 & 0.615 & 0.641 & 28 & 81 & 0.0 \\
\hline $\mathrm{C} 1 \mathrm{c}$ & & & 182 & 0.321 & 0.417 & 0.625 & 0.694 & 29 & 88 & 0.0 \\
\hline $\mathrm{C} 1 \mathrm{~d}$ & & & 211 & 0.381 & 0.394 & 0.726 & 0.765 & 31 & 90 & 0.0 \\
\hline $\mathrm{C} 2 \mathrm{~b}$ & & 4 & 154 & 0.261 & 0.219 & 0.362 & 0.216 & 41 & 89 & -22.3 \\
\hline $\mathrm{C} 2 \mathrm{c}$ & & & 182 & 0.277 & 0.252 & 0.291 & 0.316 & 44 & 89 & -33.6 \\
\hline $\mathrm{C} 2 \mathrm{~d}$ & & & 212 & 0.271 & 0.267 & 0.312 & 0.409 & 41 & 71 & -31.2 \\
\hline $\mathrm{C} 3 \mathrm{~b}$ & & 2 & 151 & 0.282 & 0.213 & 0.550 & 0.244 & 56 & 73 & -16.1 \\
\hline $\mathrm{C} 3 \mathrm{c}$ & & & 182 & 0.291 & 0.240 & 0.576 & 0.306 & 41 & 90 & -30.2 \\
\hline $\mathrm{C} 3 \mathrm{~d}$ & & & 212 & 0.305 & 0.242 & 0.404 & 0.270 & 54 & 90 & -22.6 \\
\hline $\mathrm{C} 4 \mathrm{~b}$ & & 1 & 151 & 0.306 & 0.194 & 0.691 & 0.247 & 53 & 99 & -8.9 \\
\hline $\mathrm{C} 4 \mathrm{c}$ & & & 182 & 0.387 & 0.221 & 0.676 & 0.320 & 53 & 100 & -7.2 \\
\hline $\mathrm{C} 4 \mathrm{~d}$ & & & 212 & 0.414 & 0.368 & 0.703 & 0.477 & 54 & 71 & 5.1 \\
\hline D1b & 0.35 & None & 151 & 0.349 & 0.308 & 0.694 & 0.609 & 31 & 86 & 0.0 \\
\hline D1c & & & 183 & 0.335 & 0.310 & 0.628 & 0.427 & 26 & 89 & 0.0 \\
\hline D1d & & & 211 & 0.361 & 0.309 & 0.615 & 0.508 & 29 & 74 & 0.0 \\
\hline $\mathrm{D} 2 \mathrm{~b}$ & & 4 & 150 & 0.260 & 0.219 & 0.518 & 0.237 & 44 & 89 & -25.5 \\
\hline $\mathrm{D} 2 \mathrm{c}$ & & & 181 & 0.315 & 0.257 & 0.348 & 0.320 & 44 & 90 & -6.0 \\
\hline $\mathrm{D} 2 \mathrm{~d}$ & & & 211 & 0.357 & 0.285 & 0.422 & 0.311 & 44 & 74 & -1.1 \\
\hline D3b & & 2 & 150 & 0.210 & 0.188 & 0.154 & 0.301 & 60 & 118 & -39.8 \\
\hline $\mathrm{D} 3 \mathrm{c}$ & & & 180 & 0.290 & 0.259 & 0.435 & 0.442 & 54 & 90 & -13.4 \\
\hline $\mathrm{D} 3 \mathrm{~d}$ & & & 211 & 0.325 & 0.316 & 0.327 & 0.588 & 44 & 90 & -10.0 \\
\hline $\mathrm{D} 4 \mathrm{~b}$ & & 1 & 150 & 0.217 & 0.199 & 0.269 & 0.164 & 53 & 100 & -37.8 \\
\hline $\mathrm{D} 4 \mathrm{c}$ & & & 181 & 0.327 & 0.286 & 0.368 & 0.404 & 44 & 92 & -2.4 \\
\hline $\mathrm{D} 4 \mathrm{~d}$ & & & 211 & 0.328 & 0.284 & 0.421 & 0.477 & 29 & 86 & -9.1 \\
\hline $\mathrm{E} 2 \mathrm{~b}$ & 0.5 & 4 & 151 & 0.314 & 0.219 & 0.657 & 0.233 & 46 & 90 & -0.3 \\
\hline E2c & & & 182 & 0.304 & 0.289 & 0.458 & 0.542 & 36 & 74 & -34.9 \\
\hline E2d & & & 213 & 0.343 & 0.363 & 0.428 & 0.577 & 44 & 91 & -7.4 \\
\hline E3b & & 2 & 151 & 0.267 & 0.280 & 0.361 & 0.454 & 44 & 94 & -11.1 \\
\hline E3c & & & 182 & 0.304 & 0.305 & 0.368 & 0.498 & 46 & 89 & -34.7 \\
\hline E3d & & & 212 & 0.309 & 0.323 & 0.353 & 0.588 & 44 & 94 & -17.6 \\
\hline E5b & & 8 & 151 & 0.274 & 0.227 & 0.362 & 0.409 & 44 & 89 & -12.5 \\
\hline E5c & & & 182 & 0.296 & 0.289 & 0.393 & 0.423 & 44 & 89 & -12.5 \\
\hline E5d & & & 213 & 0.291 & 0.343 & 0.445 & 0.620 & 41 & 89 & -12.5 \\
\hline
\end{tabular}

Note: $h_{1}$ and $h_{2}=$ depth of the first and second scour holes; $\operatorname{ScLoc}_{1}$ and $\mathrm{ScLoc}_{2}=$ location of the first and second scour holes; $\tan \beta_{1}$ and $\tan \beta_{1}=\operatorname{maximum}$ bed slopes in the tangential direction for the first and second scour holes.

distance between them $e$, herein evaluated in length scale). A line representing an ensemble average over all the points is represented in Fig. 9 with the corresponding upper and lower limits given by the standard deviation of the data.

By placing vertical ribs on the outer bank, the scour depth can be reduced up to about $40 \%$. When averaged over the slope, the results in terms of scour reduction do not show any particular trend with the slope (cf. Table 2). In Hersberger (2003), detailed and extensive information is given supporting these results. Fig. 9, based on systematic experiments, shows that the scour is most reduced if the ribs are placed every $2-4^{\circ}$ in a $90^{\circ}$ bend (see the averaged line). For rectangular ribs, Gairola (1996) found that the separation zone behind the ribs is about 12 times the rib depth in straight reach, based on numerical investigation. When spacing between macrorough elements is above the separation length, flow reattachment is verified and interaction between elements does not exist. If spacing between macrorough elements is less than the separation length, a general roughness-wake effect is formed in the flow, producing a phenomenon similar to Morris's wake-interference flow (Morris 1959). In this case, and as stated earlier, densely placed ribs behave like a uniformly distributed wall roughness contributing instead to a reduction in the usable channel width. This recirculation zone is responsible for head loss due to the macroroughness; the optimum rib spacing should be near the length of this separation zone corresponding to where the most efficient interaction between ribs happens.

Fig. 9 shows that from the tested cases, the rib spacing $2^{\circ}$ $\left(e / e_{d}=11.35\right)$ and $4^{\circ}\left(e / e_{d}=22.70\right)$ behave similarly and 

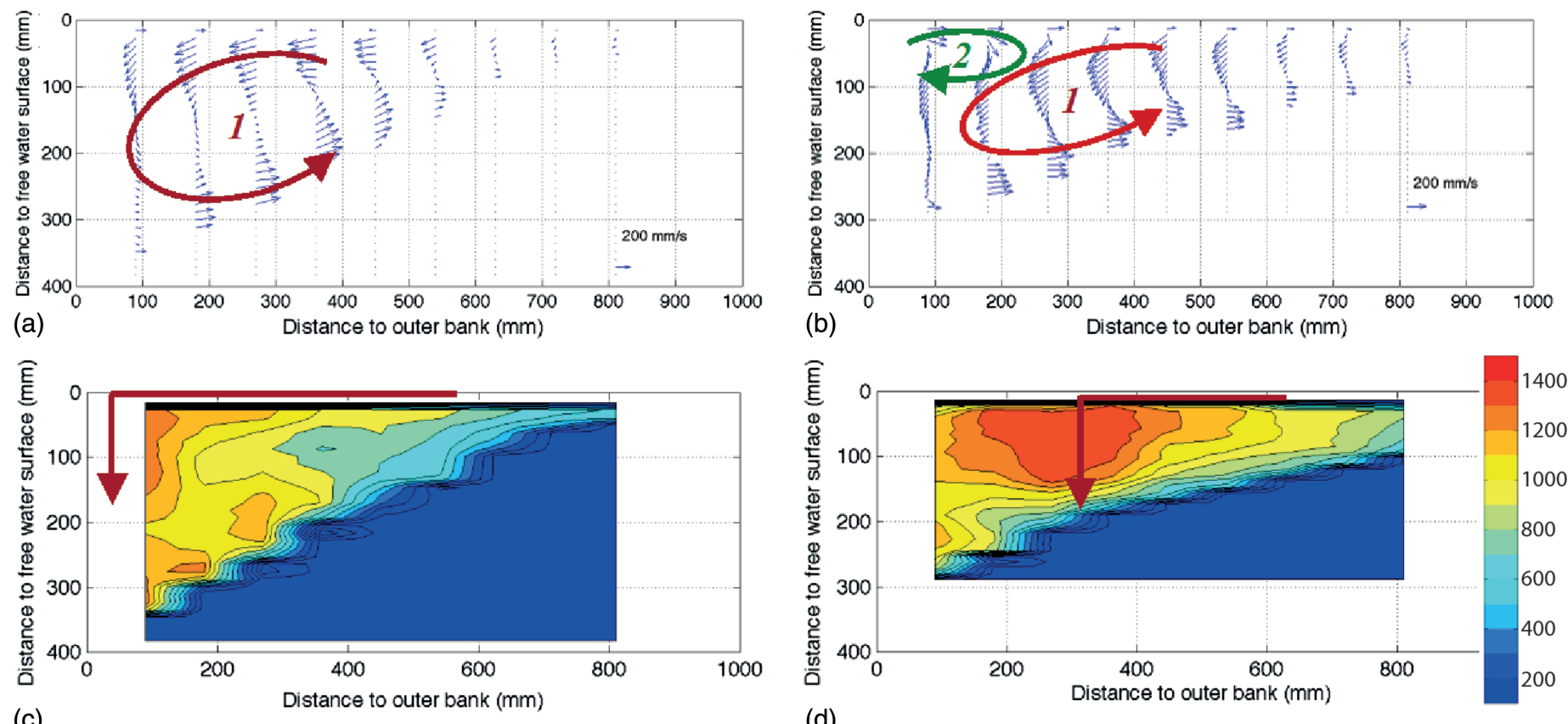

(c)

(d)

Fig. 8. (Color) Cross-section distribution of ( $\mathrm{a}$ and $\mathrm{b}$ ) transverse and (c and d) tangential time-averaged velocities for experiments with longitudinal slope of $0.50 \%$ and discharge of about $210 \mathrm{~L} / \mathrm{s}$, for situations (a and c) without ribs (B1d) and (b and d) with vertical ribs positioned at the outer bank at $4^{\circ}\left(e_{d}=20\right.$-mm-thick ribs, B2d); the figure presents the velocity field for the position $40^{\circ}$, inside the scour hole formed for experiment without macrorough walls, B1d (cf. Fig. 4); arrows in the figure indicate velocity cells with streamwise axes identified by analysis of the velocity measurements: the colors indicate the rotation direction, red for negative and green for positive

correspond to the larger scour reduction; these values are comparable to Gairola's observations. The depth of the trapezoidal vertical ribs at the outer wall should not be higher than 2.5 times the mean diameter of the bed material, since for deeper ribs $\left(5 d_{m}\right)$ local scour around their insertion into the channel bed was observed during the tests.

To obtain a smooth transition of the flow, additional ribs should be placed in the straight reach upstream and downstream of the bend at the outer wall. The model tests revealed that good results are obtained if this transition corresponds at least 10 times the mean flow depth. The ribs should be placed in these transition zones with an increasing spacing starting from the bend by using a factor of $\sqrt{2}$ compared to the previous spacing.

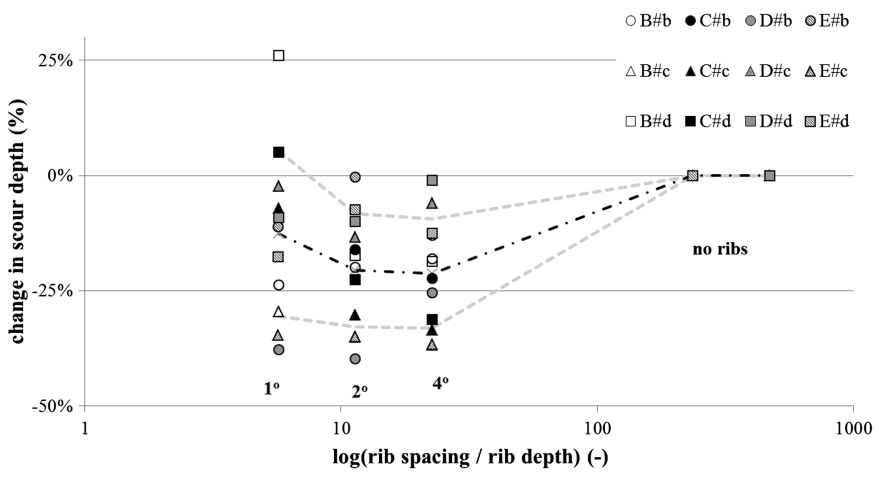

Fig. 9. Scour reduction as a function of the ratio $e / e_{d}$; scour reduction is defined, within the same group of tests (same slope and same discharge, cf. Table 1); the dark dotted-dashed line represents an ensemble average over all the points and the gray lines correspond to the upper and lower limits given by the standard deviation of the data

\section{Application Range}

Vertical ribs at protection walls for scour reduction have been applied to several flood protection projects where mountain rivers cross villages and where river banks have to be protected with vertical walls due to lack of space. The first example realized, and which motivated our study, is illustrated with Fig. 1(a). Transferring the results of the authors' flume study to this prototype case (channel width) reveals a scale of 1:30. The flood protection project of Gurtnellen has been also verified with a separate model study in a scale of 1:60, which was considered to present correctly bed load transport phenomena according to the Shields criteria (Bezzola et al. 1990). Thus, the results of this study may be used up to a scale of $1: 40$ to $1: 60$ depending on the grain-size distribution of the bed load material. The ratio of water depth to the mean diameter of the bed load is about 15 in the present study, which is a typical value found in alpine rivers. Furthermore, in the study a $90^{\circ}$ bend has been chosen in order to have well-pronounced bend scours and to see clearly the influence of the ribs at the outer bank wall. Such a bend may be extreme for alpine river conditions transporting coarse gravel material. Nevertheless the value $R / B=6$ may be considered as typical for bends in alpine rivers. In this range of application, the results may be transferred to real applications. Based on the analysis of the experimental results with a genetic algorithm, Hersberger (2003) suggested an empirical formula, which may be used in its range of application.

\section{Conclusions}

The effect of vertical ribs, placed as macroroughness elements on the outer vertical wall of a $90^{\circ}$ laboratory channel bend, was investigated in terms of impact on the bed morphology as well as in the flow velocity field. In terms of flow hydrodynamics, the results of 
time-averaged velocity fields showed that macroroughness in the outer bank makes the maximum velocity cell, observed near the outer bank for smooth outer walls, move towards the center of the channel. The high longitudinal velocities are shifted from the outer wall towards the inner wall by a distance of about one time the mean water depth.

Macrorough outer banks changed considerably the bed topography under equilibrium conditions, namely in terms of the number and position of scour holes and adjacent bars observed. In the presence of a rough outer wall, lateral bed slopes are smoothened and the amount of sediments exchanged laterally is considerably reduced. The temporal evolution shows that important oscillations of the bed level during the formation of the scour are reduced and even suppressed for high discharges. Macrorough outer walls can reduce the scour maximum depth up to about $40 \%$. However, when spacing between vertical ribs is too reduced, these act as uniformly distributed wall roughness, contributing to the width reduction due to the occupation of the cross-section, increasing consequently the flow velocity with negative effects in scour protection measures.

The use of ribs as macroroughness on the outer bend wall reduces the sediment transport capacity in the bend. Nevertheless, this reduction is compensated in natural rivers by a steepening of the bed slope, the latter being the result of sediment deposits upstream of the bend. The vertical ribs divert the flow at the downstream end of the bend towards the center of the channel where additional erosion occurs. No civil structures are normally endangered by this limited local erosion except bridge piers.

\section{Acknowledgments}

The research project was sponsored by the Swiss National Science Foundation under Grant No. 2100-052257.97/1 and 20-59382.99 and the Swiss Federal Office of Water and Geology (now Office of Environment). The authors thank the reviewers and the associate editor for their comments and suggestions, which helped to improve the quality of the paper.

\section{Notation}

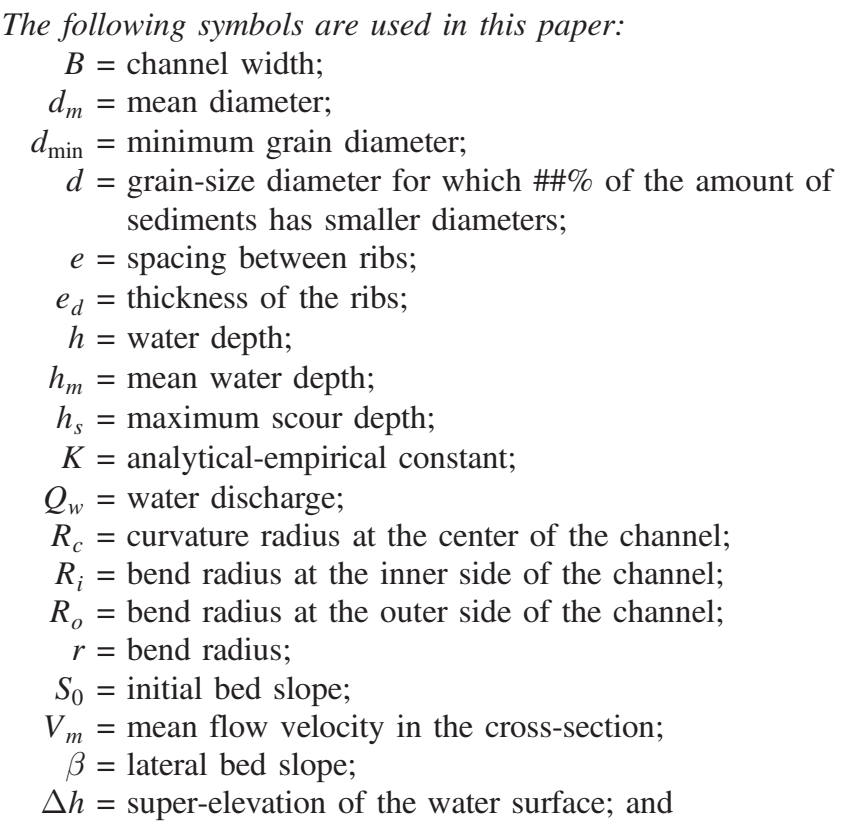

$\sigma=$ parameter characterizing the scatter of the granulometric curve.

\section{References}

Abad, J. D., and Garcia, M. H. (2009). "Experiments in a high-amplitude Kinoshita meandering channel: 1. Implications of bend orientation on mean and turbulent flow structure." Water Resour. Res., 45(2), W02401.

Abad, J. D., Rhoads, B. L., Güneralp, İ., and Garcia, M. H. (2008). "Flow structure at different stages in a meander-bend with bendway weirs." J. Hydraul. Eng., 10.1061/(ASCE)0733-9429(2008)134:8(1052), 1052-1063.

Atsuyuki, D. (1992). "Control of local scour in bend channel by roughness on embankment." 5th Int. Symp. on River Sedimentation, UNESCO, Paris, 61-70.

Bathurst, J. C., Thorne, C. R., and Hey, R. D. (1977). "Direct measurements of secondary currents in river bends." Nature, 269(5628), 504-506.

Bezzola, G. R., Kuster, P., and Pellandini, St. (1990). "The Reuss river flood of 1987-Hydraulic model tests and reconstruction concepts." Proc., Conf. on River Flood Hydraulics, Wiley, Chichester, U.K.

Bhuiyan, F., Hey, R. D., and Wormleaton, P. R. (2010). "Bank-attached vanes for bank erosion control and restoration of river meanders." J. Hydraul. Eng., 10.1061/(ASCE)HY.1943-7900.0000217, 583-596.

Blanckaert, K. (2002). "Flow and turbulence in sharp open-channel bends." Ph.D. thesis, Ecole Polytechnique Fédérale de Lausanne, Lausanne, Switzerland.

Blanckaert, K., Constantinescu, G., Uijttewaal, W., and Chen, Q. (2013). "Hydro- and morphodynamics in curved river reaches-Recent results and directions for future research." Adv. Geosci., 37(37), 19-25.

Blanckaert, K., and De Vriend, H. (2004). "Secondary flow in sharp openchannel bends." J. Fluid Mech., 498(1), 353-380.

Blanckaert, K., Duarte, A., Chen, Q., and Schleiss, A. J. (2012). "Flow processes near smooth and rough (concave) outer banks in curved open channels." J. Geophys. Res.: Earth Surf., 117(F4), F04020.

Blanckaert, K., Duarte, A., and Schleiss, A. J. (2010). "Influence of shallowness, bank inclination and bank roughness on the variability of flow patterns and boundary shear stress due to secondary currents in straight open-channels." Adv. Water Resour., 33(9), 1062-1074.

Blanckaert, K., and Graf, W. H. (2004). "Momentum transport in sharp open-channel bends." J. Hydraul. Eng., 10.1061/(ASCE)0733-9429 (2004)130:3(186), 186-198.

Chèvre, P., and Schleiss, A. J. (2005). "Influence of the macro-roughness of a bank protection by rip-rap on bed load transport and local scouring in river bends." Proc., XXXI IAHR Congress, Korean Water Resources Association, Seoul, 1356-1365.

Choi, K.-S. (2000). "Drag reduction research at the University of Nottingham." Eur. Res. Community Flow Turbul. Combust. Bull., 22, $15-21$.

Dugué, V., Blanckaert, K., Chen, Q., and Schleiss, A. J. (2013). "Reduction of bend scour with an airbubble screen-Morphology and flow patterns." Int. J. Sediment Res., 28(1), 15-23.

Fargue, L. (1868). "Study of the correlation between the configuration and the water depth in rivers with mobile bed mobile." Annales des Ponts et Chaussées, 38, 34-92.

Gairola, A. (1996). "Finite element solutions of fluid flow with heat transfer past obstructions." Ph.D. thesis, Dept. of Civil Engineering, Univ. of Roorkee, India, 212.

Hersberger, D. S. (2002). "Measurement of 3D flow field in $90^{\circ}$ bend with ultrasonic Doppler velocity profiler." 3rd Int. Symp. on Ultrasonic Doppler Methods for Fluid Mechanics and Fluid Engineering, École Polytechnique Fédérale de Lausanne, Lausanne, Switzerland, 59-66.

Hersberger, D. S. (2003). "Wall roughness effects on flow and scouring in curved channels with gravel bed." Ph.D. thesis, Laboratory of Hydraulic Constructions ( $\mathrm{LCH})$, Ecole Polytechnique Fédérale de Lausanne (EPFL), Lausanne, Switzerland.

Jamieson, E. C., Rennie, C. D., and Townsend, R. D. (2013a). "3D flow and sediment dynamics in a laboratory channel bend with and without 
stream barbs (submerged groynes)." J. Hydraul. Eng., 10.1061/(ASCE) HY.1943-7900.0000655, 154-166.

Jamieson, E. C., Rennie, C. D., and Townsend, R. D. (2013b). “Turbulence and vorticity in a laboratory channel bend at equilibrium clear-water scour with and without stream barbs (submerged groynes)." J. Hydraul. Eng., 10.1061/(ASCE)HY.1943-7900.0000673, 259-268.

Johannesson, H., and Parker, G. (1989). "Velocity redistribution in meandering rivers." J. Hydraul. Eng., 10.1061/(ASCE)0733-9429(1989) 115:8(1019), 1019-1039.

Martin-Vide, J. P., Roca, M., and Alvarado-Ancieta, C. A. (2010). "Bend scour protection using riprap." Proc. Inst. Civ. Eng.-Water Manage., 163(10), 489-497.

Metflow. (2000). "UVP monitor model UVP-XW-Users guide, March 2000." Lausanne, Switzerland.

Morris, H. M. (1959). "Design methods for flow in rough conduits." J. Hydraul. Eng., 85(7), 43-62.

Odgaard, A. J. (1981). "Transverse bed slope in alluvial channel bends." J. Hydraul. Div., 107(12), 1677-1694.

Odgaard, A. J., and Bergs, M. A. (1988). "Flow processes in a curved alluvial channel." Water Resour. Res., 24(1), 45-56.

Odgaard, A. J., and Spoljaric, A. (1986). "Sediment control by submerged vanes." J. Hydraul. Eng., 10.1061/(ASCE)0733-9429(1986)112: 12(1164), 1164-1180.

Odgaard, A. J., and Wang, Y. (1991). "Sediment management with submerged vanes. 1. Theory." J. Hydraul. Eng., 10.1061/(ASCE)0733 -9429(1991)117:3(267), 267-267.

Przedwojski, B. (1995). "Bed topography and local scour in rivers with banks protected by groynes." J. Hydraul. Res., 33(2), 257-273.

Reindl, R. (1994). "Formation of the river bed and stream pattern in a soil sequence with and without backwater effects." Ph.D. thesis, Institut für Wasserbau, Leopold-Franzens-Universität, Innsbruck (in German).
Rhodes, D. G., and Senior, A. K. (2000). "Numerical study of resistance with rib roughness of various scales." J. Hydraul. Eng., 10.1061/ (ASCE)0733-9429(2000)126:7(541), 541-546.

Roca, M., Martin-Vide, J. P., and Blanckaert, K. (2007). "Reduction of bend scour by an outer bank footing: Footing design and bed topography." J. Hydraul. Eng., 10.1061/(ASCE)0733-9429(2007) 133:2(139), 139-147.

Schleiss, A. (2000). "Bank protection at mountain rivers." Wasser, Energie, Luft, 92, 271-280 (in German).

Schleiss, A., and Hersberger, D. (2001). "Grain sorting process and scour in a curved channel with coarse gravel bed." Vol. 2, Proc., 29th IAHR Congress, Tsinghua University Press, Beijing, 140-145.

Sloff, C. J., Mosselman, E., and Sieben, J. (2006). "Effective use of nonerodible layers for improving navigability." Proc., River Flow 2006, Taylor \& Francis, London.

Sukhodolov, A. N. (2012). "Structure of turbulent flow in a meander bend of a lowland river." Water Resour. Res., 48(1), W01516.

Sukhodolov, A. N., Uijttewaal, W. S. J., and Engelhardt, C. (2002). "On the correspondence between morphological and hydrodynamical patterns of groyne fields." Earth Surf. Process. Landforms, 27(3), 289-305.

Teraguchi, H., Nakagawa, H., Kawaike, K., Baba, Y., and Zhang, H. (2011). "Effects of hydraulic structures on river morphological processes." Int. J. Sediment Res., 26(3), 283-303.

van Balen, W., Uijttewaal, W. S. J., and Blanckaert, K. (2009). "Large-eddy simulation of a mildly curved open-channel flow." J. Fluid Mech., 630, 413-442.

Voisin, A., and Townsend, R. D. (2002). "Model testing of submerged vanes in strongly curved narrow channel bends." Can. J. Civ. Eng., 29(1), 37-49.

Zeng, J., Constantinescu, G., Blanckaert, K., and Weber, L. (2008). "Flow and bathymetry in sharp open-channel bends: Experiments and predictions." Water Resour. Res., 44(9), W09401. 